\title{
Human as a Change Agent in Proactive Behavior at Work: A 70-Year Review
}

\author{
Rusyda, H. M, Nik Hairi, O, Asmuni Abd Ghani
}

To Link this Article: http://dx.doi.org/10.6007/IJARBSS/v10-i9/7838

DOI:10.6007/IJARBSS/v10-i9/7838

Received: 07 June 2020, Revised: 12 July 2020, Accepted: 15 August 2020

Published Online: 30 September 2020

In-Text Citation: (Rusyda, Hairi, \& Ghani, 2020)

To Cite this Article: Rusyda, H. M., Hairi, N. O., \& Ghani, A. A. (2020). Human as a Change Agent in Proactive Behavior at Work: A 70-Year Review. International Journal of Academic Research in Business and Social Sciences. 10(9), 612-628.

\section{Copyright: (C) 2020 The Author(s)}

Published by Human Resource Management Academic Research Society (www.hrmars.com)

This article is published under the Creative Commons Attribution (CC BY 4.0) license. Anyone may reproduce, distribute, translate and create derivative works of this article (for both commercial and non-commercial purposes), subject to full attribution to the original publication and authors. The full terms of this license may be seen at: http://creativecommons.org/licences/by/4.0/legalcode

Vol. 10, No. 9, 2020, Pg. 612 - 628 


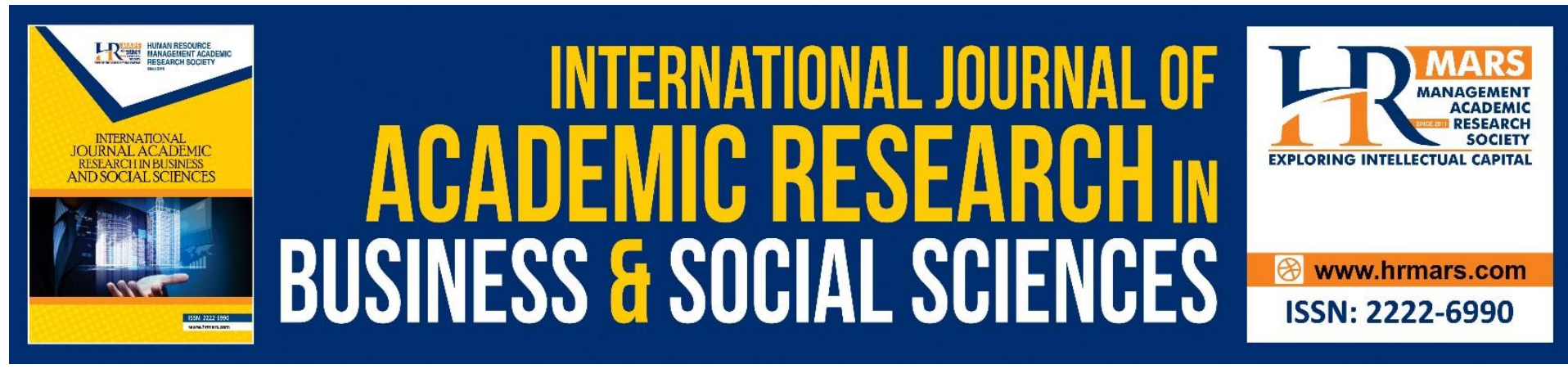

\title{
Human as a Change Agent in Proactive Behavior at Work: A 70-Year Review
}

\author{
Rusyda, H. M, Nik Hairi, O, Asmuni Abd Ghani
}

Human Development Program, Center for Research in Psychology and Human Well-Being, Faculty of Social Sciences and Humanities, Universiti Kebangsaan Malaysia

Email: hairi@ukm.edu.my

\begin{abstract}
Proactive employees have become the core focus as the main mechanism through which to achieve an organizational goal centered on profit-making and productivity. From a classical behaviorist perspective, individual differences are the predominant factor in maintaining proactive behavior. However, individual differences vary, ranging from individual personality to motivational determinant. Although a proactive personality is believed to have led to proactive behavior, contemporary studies have found otherwise. Indeed, studies have discovered that proactive behavior is supported mainly by the motivational mechanism. Individuals will engage in proactive behavior only if they have the confidence to do so and understand the reasons behind such conduct. These findings are consistent with Bandura's research on behavior that emphasizes the importance of human internalization in behavior engagement.
\end{abstract}

\section{Introduction}

Seventy years ago, physiologists and classical behavioral researchers began the journey of understanding behavior, eventually influencing the discovery of proactive behavior. This inception was unintentional, but later became the most significant study of behavioral research. Classical behavioral researchers who intended to understand physiology and brain neurons coincidentally observed a continuous process of conditioning and stimulus-response during the experiment. The classical behavior approach suggested that behavioral engagement was supported by the learning process: that organisms will engage in certain behavior based on what is learned from the environment (Zakaria, Aun, \& Hamat, 2018). Proactive behavior is a crucial and definitive element of organizational behavior research because it explains future-focused behavior, self-initiative, and efforts to improve how work is being done to maximize performance (Brosi, Sporrle, \& Welpe, 2018).

In this paper, we will explain the social learning theory and social cognitive theory proposed by Bandura and examine their relationship with the emergence of proactive behavior. This is followed by an analysis of the current trends of proactive behaviors, such as job crafting and the process of future-focused proactive behavior. This exploration uses a chronological arrangement to explain the connecting point between the theories and, in particular, assess 
the importance of motivational mechanisms and environmental support in developing and maintaining proactive behavior.

The Impact of the Social Learning Theory

Propounded by Albert Bandura (1970), the social learning theory is recommended as the most wide-ranging theory in social learning (Rosenthal \& Zimmerman, 1978). The theory strongly criticized behaviorism as "rigid", suggesting that it abandoned cognitive functioning when explaining behavior (Bandura, 1971). The social learning theory is a 'bridging' effort to link three important aspects in understanding behavior: psychoanalytic, learning, and behavioral outcomes (Bandura, 1978). While Bandura criticized behaviorism as being "extreme" (Fox, 2006), however, the social learning theory recognizes Skinnerian stimulus and reinforcement as two main elements in understanding behavior (Bandura, 2006a; Kenrick \& Dantchik, 1983). The theory developed from the results of the Bobo Doll Experiment, which intended to identify children's behavioral changes following a certain amount of exposure to aggressive behavior (Bandura, 1977, 2006b; Elkjaer, 1999). Bandura suggested that behavior is developed through direct experience and modeling, in contrast to Pavlovian and Skinnerian theories, which proposed that behavior can emerge only via external environment factors (Hairi, Awang, \& Manaf, 2012).

There are four principles of modeling in the social learning theory: the attentional process, the retention process, the motoric reproduction process, and the process of reinforcement and motivation. This cyclical procedure is deemed necessary for modeling to take place (Neziroglu, Khemlani-Patel, \& Veale, 2008). The attentional process is also known as a state of arousal, where individuals monitor the behavior and then absorb all necessary information relating to it (Grison, Tipper, \& Hewitt, 2005). In this stage, the individuals will use both visual and cognitive ability to capture and store information in the brain (Robbins, 2002). The next step is the retention process, where all the stored information is translated into two fields: imaginary and verbal coding. For modeling to take place, the individuals must have the ability to envision the sequences of the anticipated behavior whilst simultaneously creating verbal coding for each sequence (Tu, 2000). Verbal coding can be in the form of mnemonics or symbols that are comprehended by the individuals (Rosenthal \& Zimmerman, 1978). During the motoric reproduction process, the individuals exhibit behavior according to the imagined sequences and the coding: this behavior must be witnessed by another party to give feedback (Lambropoulos, 2004). Such responses are necessary so that individuals can improve and imitate behavior better (Al-Shboul, Maros, \& Mohd Yasin, 2012). The final process is the functional role of reinforcement and motivation. It has been suggested that tangible and intangible reinforcement both play a significant role in behavioral engagement among individuals (Williams et al., 1972) but any negative reinforcement may dampen or deactivate the overt behavior.

Social Cognitive Theory: Human as a Change Agent

As we have seen, Bandura's social learning theory contributed to the area of behavioral research area quite significantly by introducing cognitive functioning, two ways of learning, and the role of reinforcement (McAleer, 1975). After many years, however, Bandura introduced an improved version of the theory in 1989, named the social cognitive theory (Bandura, 1989b). In the early stages of development, Bandura outlined the social cognitive theory as a model stimulated by the emergent interactive agency (Bandura, 1986; 1997a), 
though he later undertook a thorough examination of triadic reciprocal determinism and selfdirectedness (Bandura, 1991; Bandura, Adams, \& Beyer, 1977; Nabavi, 2015) to strengthen the concept of the emergent interactive agency further. Bandura maintained the importance both of reinforcement as motivation and of cognitive functioning in behavioral observation (Bandura, 1999; Elkjaer, 1999). The fundamental principle of this theory focuses on the importance of the psychosocial in behavioral change (Bandura, 1998). Indeed, Bandura unambiguously emphasized the self or the human as an agent in exacting behavioral change (Bandura, 1982, 1989a, 2001). Nonetheless, Bandura argued that the cognitive mechanism was the most significant regulator in social cognitive theory, as opposed to the environment or the people involved (Khajehpour, Ghazvini, Memari, \& Rahmani, 2011; Swearer, Wang, Berry, \& Myers, 2014).

\section{Triadic Reciprocal Determinism}

Pavlov and Skinner argued through their research that behavior is developed according to environmental factors. This research, however, neglected the functioning role of the person or individuals, the importance of which was then highlighted by Bandura (Skinner, 2014; Wolpe \& Plaud, 1997). In his social cognitive theory, Bandura claimed that the relationship between behavior, person, and environment should be observed as triadic reciprocal determinism: indeed, that those three elements all affect and influence one other (Wood \& Bandura, 1989). This is not a unidirectional relationship, as suggested in the research of Pavlov and Skinner; instead, it involves a reciprocal relationship, or, "affecting and being affected" (Bandura, 1994; Rosenstock, Strecher, \& Becker, 1998).

The dynamic process of triadic reciprocal determinism, as presented in Figure 1, explained that behavior is not a product of interactions between other elements, in contrast to the behaviorist approach (Hicks, 2005; Mathibe, 2008). Instead, this model asserted that with attitudes, personality, and motivation, a person can engage in productive behavior (McAuley, 1992). Moreover, if a person observes behavior that results in a positive outcome for themselves or others, they will opt for a self-regulatory approach, modifying their resources to achieve such outcomes (Seigfried-Spellar \& Rogers, 2010). The Person-Environment interaction suggests that socialization and reinforcement can enable changes in a person (Rido, Nambiar, \& Ibrahim, 2016). Observation, modeling, and extrinsic motivation can coordinate human cognitive properties and modify personal characteristics (Bandura, 1978b, 1983), which then consequently alter the environment (Gruber, 2011). The BehaviorEnvironment relationship is similar to the behaviorism approach (Glanz \& Mullis, 1988), yet is distinct in its approach to the bidirectional relationship as recommended by Bandura. In this relationship, the behavior is perceived both as an agent that changes the environment and a product of the environment. The environment is defined as physical surroundings and stimuli, including the people, the condition, or the reinforcement that impacts the behavior (Berlin, Norris, Kolodinsky, \& Nelson, 2013). The environment will determine the regularities of behavior enactment (Lam, Kraus, \& Ahearne, 2010; Robbins, 2002). Finally, through the constant envisioning of a productive consequence (Chang, McKeachie, \& Lin, 2010), individuals will continuously attempt to change the environment in a way that benefits them for the future (Bellows et al., 2011; Benight, Cieslak, Molton, \& Johnson, 2008). 


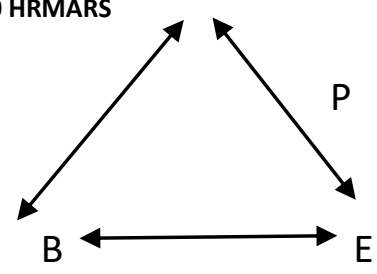

Figure 1. Triadic Reciprocal Determinism

Self-Efficacy and Human Agency

Self-efficacy is often considered as the self-confidence required to successfully perform a task (Bandura, 2001; McCormick, 2001). Self-efficacy is part of a motivational hub (Hoy \& Spero, 2005; Rosenstock et al., 1998; Yi \& Hwang, 2003): humans should have the confidence to perform a job and understand the importance of the job to them; these behaviors are internally or externally reinforced and work towards a goal (Bandura, 2004; Strecher, DeVellis, Becker, \& Rosenstock, 1986). Bandura highlighted that the strengths of social cognitive theory and behavioral change lie in the cognitive resources of a person. In social cognitive theory, these cognitive resources encompass personal mastery, a person's ability to process information, and the self-motivation necessary for behavioral enactment and to visualize the processes of behavioral engagement and self-evaluation (Esue, Tseng, \& Wirtz, 2005). An individual's level of self-efficacy is based on the difficulty of the task and previous outcomes they have achieved, or on the influences shown on the people around them (Bandura \& Schunk, 1981; Schunk, 1991; Yi \& Hwang, 2003). Other research has also confirmed that a person with a high level of self-efficacy often performs better at a job than those with low self-efficacy (Lavoie, Ouellet, Hamelin, \& Bénard, 2004; Merriam, 1995).

However, self-efficacy is not an independent mechanism; it is, rather, part of a self-regulatory system (Marcuss, Selby, Niaura, \& Rossi, 1992), and is considered a dominant precursor to behavioral change (Dzewaltowski, Noble, \& Shaw, 1990). A self-regulatory system is defined as a process of future-focused goal attainment through cognitive abilities (Vohs \& Baumeister, 2011). The potential of self-regulation has frequently been neglected; indeed, organizations have often underestimated the potency of self-directedness and selfmanagement in goal achievement (Boekaerts, Pintrich, \& Zeidner, 2005). Self-regulation is highly depended upon in organizations with little hierarchy and constraints with sufficient social support (Braziene, Merkys, \& Mikutaviciene, 2015). Through the principles of the selfregulatory system, humans can control and use their cognitive resources (Zhao, Lu, Wang, \& Huang, 2011; Zimmerman, 2014), be self-motivated and self-directed, and constantly work to achieve a pre-determined goal and objective (Marcuss et al., 1992). Moreover, locus of control is an outcome control that is often exhibited by individuals with a high level of selfefficacy (Zimmerman, 2014; Zimmerman, Bandura, \& Martinez-Pons, 1992). Therefore, with the integration of locus of control and self-efficacy, individuals who have a predetermined goal will not anticipate any fortuity, due to their confidence, efforts, and thorough systematic process towards goal achievement (Zimmerman, 2000). Individuals will monitor the achieved behavioral outcomes and their effects before making decisions for further behavioral engagement (Thang, Mahmud, \& Abd Razak, 2012).

\section{The Emergence of Proactive Behaviour}

In his social cognitive theory, Bandura described the self-efficacy of a person as the most reliable predictor in behavior production (Bandura, 1989b). In his papers, he also noted the influence of personal factors on behavior but neglected to discuss the effects of personality 
(Bandura, 1978a; Nabavi, 2015). He argued, however, that personality is part of the biological properties of a person (McCormick, 2001; Staddon, 1984) and should be explored as another mechanism in understanding behavior (Bandura, 1978; Khajehpour et al., 2011). This research has motivated further behavioral studies that encompass both personality and behavior.

At the beginning of the 1990s, proactive behavior was explained by a modern theoretical perspective, replacing the traditional classical theory of behaviorism propounded by Skinner and Pavlov. The theory was highly influenced by the interactionism perspective adopted by the Field Theory (Lewin, 1936), based on the formula " $B=f(P \times E)$, " where B is Behavior, $P$ is Person and $E$ is the Environment; it also applied social cognitive theory in assessing the extent to which the interaction of the person and the environment can determine behavior (Bryan \& Hester, 2012; Petrou, Demerouti, Peeters, Schaufeli, \& Hetland, 2012). In 1993, Bateman and Crant initiated a scale of personal disposition as proactive constructs to measure proactive behavior. An individual with a proactive personality was described by Bateman and Crant as "one who is relatively unconstrained by situational forces, and who effects environmental change"; they also suggested that "proactive people scan for opportunities, show initiative, take action, and persevere until they reach closure by bringing about change" (p. 105). This personal characteristic is unique, and is not possessed by all employees (Bolino, Valcea, \& Harvey, 2010). Proactive personality is linked to individual differences and can be considered the key predictor of proactive behavior (Crant, 1995). Other possible factors such as motivation and contextual precursors, were also tested alongside proactive personality to assess its relationship with proactive behavior.

\section{Proactive Behavior: The Present}

The current trend of proactive behavior has elevated to another sphere. Indeed, proactive behavior has re-emerged and its contemporary interpretation has been broadened. Proactive behavior is no longer confined to an antecedent-outcome interaction as it was at the beginning of its application; it has instead spurred a discussion about exacting progressive change at work (Brenninkmeijer \& Hekkert-Koning, 2015; Rastogi \& Richa, 1999), and futurefocused proactive behavior (Van der Rijt, Van den Bossche, Van de Wiel, Segers, \& Gijselaers, 2012). Job crafting has become a new form of proactive behavior (Jones, Momin, Good, Shea, \& Patric, 2009; Peeters, Arts, \& Demerouti, 2016) and a systematic approach is now the central discussion on how to understand proactive behavior (Bindl \& Parker, 2010; Parker, Wang, \& Liao, 2019; Strauss \& Parker, 2018) with a goal-directed approach ( Parker \& Wang, 2015; Strauss \& Parker, 2014). The research on both job crafting and future-focused proactive behavior has contributed immensely to the literature of proactive behavior.

Job Crafting

Job crafting is a condition whereby employees alter their tasks or other job characteristics through their initiative to support their interests, enthusiasms, and desires (Bakker, Tims, \& Derks, 2012; Peng, 2018; Schaufeli, Bakker, \& Salanova, 2006a). Job crafting is also a process through which employees take control in trying to meet their interests in a way that could be of benefit at both the individual and the organizational levels (Bakker et al., 2012; Berg \& Dutton, 2013). Although job crafting is a form of proactive behavior (Thun \& Bakker, 2018), however, the constructs have shifted. Proactive behavior paradigms are related to job performance, while job crafting constructs measure the person-job fit and work motivation 
(Tims, Bakker, \& Derks, 2012). Moreover, employees who engage in job crafting do so for three innate reasons: autonomy, relatedness, and competence (Bakker, 2014; Jones et al., 2009).

Autonomy in this context refers to the freedom to decide which task to undertake, when to complete the work, and how best to do it (Bindl, Unsworth, Gibson, \& Stride, 2018). Autonomy in job crafting is connected to the motivational part of autonomous motivation from a self-determination perspective (Wilson, Mack, \& Grattan, 2008). Indeed, employees who engage in job crafting frequently work better with minimal supervision; they are given the allowance to perform their job based on their preferences, so they can be in control of their situation (Berg, Dutton, \& Wrzesniewski, 2008). Relatedness, in contrast, is about building and maintaining a social relationship at the workplace (Peng, 2018). This is essential for an employee's well-being because it offers acceptance and respect, which will in turn enhance work engagement and job satisfaction (Kooij, van Woerkom, Wilkenloh, Dorenbosch, \& Denissen, 2017). Finally, competence refers to perceived personal mastery and the capability of performing a job (Plomp et al., 2016; Slemp, Kern, \& Vella-Brodrick, 2015). Innate competency is similar to self-efficacy: it is about the individual's confidence in executing a task successfully (Mattarelli \& Tagliaventi, 2015; Rastogi \& Richa, 1999).

Future-focused Proactive Behavior

The present definition of proactive behavior in an organizational setting is a "self-starting and future-focused action that aims to bring about change, either in the self or in one's work environment" (Bindl \& Parker, 2010; Lewis, Smith, \& Lewis, 1993; Ward et al., 2014). This selfregulatory, future-focused proactive behavior is not a new approach. It was inspired by earlier research by Bandura that was associated with self-directedness and self-efficacy (Bandura, 2001; Parker, Bindl, \& Strauss, 2010; Wu, Parker, \& Bindl, 2013). As we have seen, in Bandura's social cognitive theory, it was argued that behavior should be perceived as the future-focused purpose that drives a human to build a systematic, step-by-step process towards goal attainment (Bandura, 1978b; Rosenstock et al., 1998).

The central argument of future-focused proactive behavior is based on the thinking process, through which humans construct the proactive goal, and the cognitive journey towards that process (Kirsch, Lynn, Vigorito, \& Miller, 2004; Roseman, 2013; Rotter, 1971). It is a selfregulatory system that integrates cognition, representation, motivation, and behavior (Karoly, 1993; Richman \& Lattanner, 2014). Humans must believe that a forecasted behavior will happen, provided that all mechanisms are constructed to support such a process (Coleman \& Gormezano, 1979; Hakanen \& Schaufeli, 2012): indeed, in the self-regulatory system, the principal requirement of a future-focused proactive behavior is that the individual must have strong ownership of the goal (S. Parker et al., 2010; Wu et al., 2013). The individual has to believe that the actions and behavior will bring positive outcomes to them and also positively influence their environment, organization, or co-workers (Parker, 2013).

Future-focused proactive behavior is grounded by an intention to plan and execute the process of proactive behavior without interference from an external party (Patrick, Knee, Canevello, \& Lonsbary, 2007). It is initiated internally by the individuals, based on their potential and anticipated outcomes (Mullan, Ormcauley, Wraith, \& Duncan, 1997). However, 
external motivation can also be of assistance in future-focused proactive behavior since the process of internalization involves transforming external motivations into internal motivations (Wang \& Hou, 2015; Zhao et al., 2011): for example, a leader motivating and rewarding employees increases internal motivation (Frese, Kring, Soose, \& Zempel, 2015). This type of motivation is also known as introjected regulation: it is not self-determined and is thus considered an external motivation (Guay, Senécal, Gauthier, \& Fernet, 2003).

There are three components of motivational states that are both necessary and crucial for goal-oriented proactive behavior (Shin \& Kim, 2014; van der Rijt et al., 2012). These are selfconfidence ("can do"), expectations ("reason to"), and affects ("energized to"; Strauss, Griffin, \& Parker, 2012). Bandura similarly emphasized that in self-regulated behavior, selfefficacy should not be an independent motivation mechanism, but rather a component of a motivational hub (Bandura, 2001; Lajoie, Naismith, Health, \& Poitras, 2013). Confidence, or the "can-do" mechanism, here relates to an individual's high capacities and confidence that their actions will bring positive change to themselves and others (Hirschi, Lee, Porfeli, \& Vondracek, 2013). The second component, the expectation or "reason to", is associated with reasoning and questioning the motive behind individuals' decisions in behavioral engagement (Clarke et al., 2016). The "reason to" can be as simple as having the drive to improve situations for everyone else (S. K. Parker et al., 2019). Finally, the "energized to" mechanism is an affective aspect also known as an activation agent, that helps strengthen the two other motivational aspects (Williams, Parker, \& Turner, 2010). Highly activated, positive moods such as feeling energized are, moreover, strong predictors of proactive goal regulations (Bindl, Parker, Totterdell, \& Hagger-Johnson, 2012).

\section{Proactive Behavior at Work: A Conclusion}

This paper has examined the development of proactive behavior, from its origin in classical behavioral research to recent studies related to proactive behavior. Indeed, the literature indicates that the proactive behavior research field is dynamic and continually growing with discoveries and findings. The influence of classical behavioral research by Skinner and Pavlov to Bandura's work is unlikely to be of great significance; the ideas are, however, lightly ingrained in proactive behavior. Furthermore, motivation and environmental influences, such as social support and organizational policies are noteworthy in proactive behavior engagement.

Proactivity at work is generally characterized by initiative, such as performing a task without being asked to do so, assertiveness, and persistence in seeking positive outcomes (Crant, 2000). Proactive employees are capable of identifying or creating opportunities that are favorable for the individual and the team and contribute to organizational effectiveness (Bateman \& Crant, 1993).

Proactive behavior also relates strongly to the innate desire of humans, whether proactivity leads them to feel accepted by other organizational members (Rofcanin, Berber, Koch, \& Sevinc, 2016), proves and confirms that they can do their job (Zhang \& Parker, 2018), or enables them to believe they can change their way of working for the better (Gordon et al., 2018; Slemp et al., 2015; Thun \& Bakker, 2018). In organizations with a low level of support, however, being proactive is likely to deplete resources such as time and energy (Grant \& Ashford, 2008; Hutchins, Penney, \& Sublett, 2018), especially towards proactive behavior. Proactive employees do not operate in a social vacuum. Their potential can be somewhat increased with a sufficient level of job resources, such as opportunities for development, autonomy, and co-workers' support (Bolino et al., 2010; Thompson, 2005). 
The human factor in affecting proactive behavior is significant: this is consistent with Bandura's argument that emphasized the importance of human internal force in manifesting a set of behaviors. Although research has shown that work context, such as the level of leadership and co-workers' support, is important in proactive behavior engagement ( $\mathrm{Di}$ Marco, Arenas, Giorgi, Arcangeli, \& Mucci, 2018), the central precursor to proactive behavior engagement lies strongly in the individual's motivational component (Van den Broeck et al., 2011).

Proactive behavior is certainly a 'self-system.' It begins with self-realization: when an individual realizes that he or she has to be proactive to make changes at the workplace, they have self-confidence; they believe that they can accomplish tasks successfully and thus become self-motivated; they have justification and are continuously intrinsically motivated with an accepted level of autonomy at work. Proactive behavior is, however, much more feasible with sufficient support. The benefits are not limited to the individual; proactive behavior has the potential to positively impact one's environment, encompassing coworkers, leaders, the organization itself, and, on a larger scale, the nation as a whole.

\section{References}

Al-Shboul, Y., Maros, M., \& Yasin, M. S. (2012). An intercultural study of refusal strategies in english between jordanian EFL and malay ESL postgraduate students. $3 L$ : Language, Linguistics, Literature, 18(3), 29-39.

Bakker, A. B., Tims, M., \& Derks, D. (2012). Proactive personality and job performance: The role of job crafting and work engagement. Human Relations, 65(10), 1359-1378. https://doi.org/10.1177/0018726712453471

Bakker, A. B. (2014). The Job Demands-Resources Questionnaire.

Bandura, A. (1971). Social learning theory. Stanford University, 1-46. https://doi.org/10.1111/j.1460-2466.1978.tb01621.x

Bandura, A. (1977). Social Learing Theory (Vol. 03). https://doi.org/10.4236/psych.2012.310138

Bandura, A. (1978a). Social Learning Theory of Aggression. Journal of Communication, 28(3), 12-29. https://doi.org/10.1111/j.1460-2466.1978.tb01621.x

Bandura, A. (1978b). The self system in reciprocal determinism. American Psychologist, Vol. 33, pp. 344-358. https://doi.org/10.1037/0003-066X.33.4.344

Bandura, A. (1982). Self-Efficacy Mechanism in Human Agency. American Psychologist, 37(2), 122-147. https://doi.org/10.1016/0006-8993(86)91535-0

Bandura, A. (1983). Temporal Dynamics and Decomposition od Reciprocal Deteminism: A Reply to Philips and Orton. Psychological Review, 90(2), 166-170.

Bandura, A. (1989a). Human Agency in Social Cognitive Theory. American Psychologist, 44(9), 1175-1184. https://doi.org/10.1146/annurev.psych.52.1.1

Bandura, A. (1989b). Social Cognitive Theory. Annals of Child Development, 6, 1-60. https://doi.org/10.1111/1467-839X.00024

Bandura, A. (1991). Social Cognitive Theory of Moral Thought and Action. In W. Kurtines \& J. Gewirtz (Eds.), Handbook of Moral Behaviour and Development (pp. 45-103). Lawerence Erlbaum Associates.

Bandura, A. (1994). Social Cognitive Theory and Exercise of Control over HIV Infection. In Preventing AIDS: Theories and methods of behavioral interventions (pp. 25-59). https://doi.org/10.1007/978-1-4899-1193-3_3

Bandura, A. (1998). Organisational Applications of Social Cognitive Theory. Australian 
Journal of Management, 13(2), 138-139. https://doi.org/10.1002/ana.10031

Bandura, A. (1999). Social cognitive theory of personality. Handbook of Personality: Theory and Research 2nd Ed., 154-196. https://doi.org/10.1016/0749-5978(91)90022-L

Bandura, A. (2001). Social Cognitive Theory: An agentic perspective. Annual Review of Psychology, 52, 1-26. https://doi.org/10.1146/annurev.psych.52.1.1

Bandura, A. (2004). Health promotion by social cognitive means. Health Education and Behavior, 31(2), 143-164. https://doi.org/10.1177/1090198104263660

Bandura, A. (2006a). SOCIAL LEARNING THEORY AND AGGRESSION. Journal of Communication, 28(3), 12-29.

Bandura, A. (2006b). Toward a psychology of human agency. Perspectives on Psychological Science, 1(2), 164-180.

Bandura, A., Adams, N., \& Beyer, J. (1977). Cognitive process mediating behavioral change. Journal of Personality and Social Psyhcology, 35(3), 125-139. https://doi.org/10.1103/PhysRevC.7.1950

Bandura, A., \& Schunk, D. (1981). Cultivating competence, self-efficacy, and intrinsic interest through proximal self motivation. Journal of Personality and Social Psyhcology, 41(3), 586-598.

Bateman, T. S., \& Crant, J. M. (1993). The proactive component of organizational behavior : A measure and correlates. 14(August 1992), 103-118.

Bellows, L., Silvernail, S., Caldwell, L., Bryant, A., Kennedy, C., Davies, P., \& Anderson, J. (2011). Parental perception on the efficacy of a physical activity program for preschoolers. Journal of Community Health, 36(2), 231-237. https://doi.org/10.1007/s10900-010-9302-1

Benight, C. C., Cieslak, R., Molton, I. R., \& Johnson, L. E. (2008). Self-evaluative appraisals of coping capability and posttraumatic distress following motor vehicle accidents. Journal of Consulting and Clinical Psychology, 76(4), 677-685. https://doi.org/10.1037/0022-006X.76.4.677

Berg, J., Dutton, J., \& Wrzesniewski, A. (2008). What is job crafting and why does it matter? [Theory-to-practice briefing]. (January), 1-8.

Berg, J. M., \& Dutton, J. E. (2013). Purpose and meaning in the workplace. 81-104. https://doi.org/10.1037/14183-000

Berlin, L., Norris, K., Kolodinsky, J., \& Nelson, A. (2013). The role of social cognitive theory in farm-to-school-related activities: Implications for child nutrition. Journal of School Health, 83(8), 589-595. https://doi.org/10.1111/josh.12069

Bindl, U. K., \& Parker, S. K. (2010). Proactive work behavior: Forward-thinking and changeoriented action in organizations. APA Handbook of Industrial and Organiza- Tional Psychology, 2(2010), 567-598. https://doi.org/10.1037/12170-019

Bindl, U. K., Parker, S. K., Totterdell, P., \& Hagger-johnson, G. (2012). Fuel of the SelfStarter : How Mood Relates to Proactive Goal Regulation. 97(1), 134-150. https://doi.org/10.1037/a0024368

Bindl, U. K., Unsworth, K. L., Gibson, C. B., \& Stride, C. B. (2018). Job Crafting Revisited: Implications of an Extended Framework for Active Changes at Work. Journal of Applied Psychology. https://doi.org/10.1037/apl0000362

Boekaerts, M., Pintrich, P. R., \& Zeidner, M. (2005). Handbook of self-regulation. New York: Elsevier.

Bolino, M., Valcea, S., \& Harvey, J. (2010). Employee, manage thyself: The potentially negative implications of expecting employees to behave proactively. Journal of 
Occupational and Organizational Psychology, 83(2), 325-345. https://doi.org/10.1348/096317910X493134

Braziene, R., Merkys, G., \& Mikutaviciene, I. (2015). Employers' expectations and young workers selection criteria in Lithuania. Social Sciences, 86(4), 62-69.

Brenninkmeijer, V., \& Hekkert-Koning, M. (2015). To craft or not to craft. Career Development International, 20(2), 147-162. https://doi.org/10.1108/CDI-12-20140162

Brosi, P., Sporrle, M., \& Welpe, I. M. (2018). Do we work hard or are we just great? The effects of organizational pride due to effort and ability on proactive behavior. Business Research, 11(2), 357-373. https://doi.org/10.1007/s40685-018-0061-7

Bryan, J., Jr, F., Marler, L. E., \& Hester, K. I. M. (2012). Bridge building within the province of proactivity. 1070(January), 1053-1070. https://doi.org/10.1002/job

Chang, T. S., McKeachie, W., \& Lin, Y. G. (2010). Faculty perceptions of teaching support and teaching efficacy in Taiwan. Higher Education, 59(2), 207-220. https://doi.org/10.1007/s10734-009-9243-8

Clarke, S., Probst, T. M., Guldenmund, F., Passmore, J., Clarke, S., Probst, T. M., ... Passmore, J. (2016). The psychology of occupational safety and workplace health. In The Wiley Blackwell handbook of the psychology of occupational safety and workplace health. Retrieved from https://search.ebscohost.com/login.aspx?direct=true \&db=psyh\&AN=2015-35805001\&site=ehost-live

Coleman, S., \& Gormezano, I. (1979). Classical conditioning and the" law of effect": Historical and empirical assessment. Behaviorism, 7(2), 1-33. Retrieved from http://psycnet.apa.org/psycinfo/1981-02334-001

Crant, J. M. (2000). Proactive Behavior in Organizations. Journal of Management, 26(3), 435-462. https://doi.org/10.1177/014920630002600304

Crant, J. M. (1995). The Proactive Personality Scale and objective job performance among real estate agents. Journal of Applied Psychology, 80(4), 532-537. https://doi.org/10.1037//0021-9010.80.4.532

Di Marco, D., Arenas, A., Giorgi, G., Arcangeli, G., \& Mucci, N. (2018). Be friendly, stay well: The effects of job resources on well-being in a discriminatory work environment. Frontiers in Psychology, 9(APR), 1-8. https://doi.org/10.3389/fpsyg.2018.00413

Dzewaltowski, D. A., Noble, J. M., \& Shaw, J. M. (1990). Physical Activity Participation: Social Cognitive Theory versus the Theories of Reasoned Action and Planned Behavior. Journal of Sport and Exercise Psychology, 12(4), 388-405. https://doi.org/10.1123/jsep.12.4.388

Elkjaer, B. (1999). In search of a social learning theory. In Organizational Learning and the Learning Organizaton (pp. 75-91). London: SAGE Publications Inc.

Esue, O., Tseng, Y., \& Wirtz, D. (2005). Perceived self-efficacy in the exercise of control over AIDS infection. Physical Review Letters, 95(4), 9-17. https://doi.org/10.1103/PhysRevLett.95.048301

Fox, S. (2006). "Inquiries of every imaginable kind": Ethnomethodology, practical action and the new socially situated learning theory. Sociological Review, 54(3), 426-445. https://doi.org/10.1111/j.1467-954X.2006.00624.x

Frese, M., Kring, W., Soose, A., \& Zempel, J. (2015). PERSONAL INITIATIVE AT WORK : DIFFERENCES University of Amsterdam. 39Deme(1), 37-63.

Glanz, K., \& Mullis, R. M. (1988). Environmental interventions to promote healthy eating: A 
review of models, programs, and evidence. Health Education Quarterly, 15(4), 394415.

Gordon, H. J., Demerouti, E., Le Blanc, P. M., Bakker, A. B., Bipp, T., \& Verhagen, M. A. M. T. (2018). Individual job redesign: Job crafting interventions in healthcare. Journal of Vocational Behavior, 104, 98-114. https://doi.org/10.1016/j.jvb.2017.07.002

Grant, A. M., \& Ashford, S. J. (2008). The dynamics of proactivity at work. Research in Organizational Behavior, 28, 3-34. https://doi.org/10.1016/j.riob.2008.04.002

Grison, S., Tipper, S. P., \& Hewitt, O. (2005). Long-term negative priming: Support for retrieval of prior attentional processes. Quarterly Journal of Experimental Psychology Section A: Human Experimental Psychology, 58(7), 1199-1224. https://doi.org/10.1080/02724980443000557

Gruber, C. (2011). The psychology of courage: modern research on an ancient virtue. Integrative Psychological and Behavioral Science, 45(2), 272-279. https://doi.org/10.1007/s12124-011-9155-x

Guay, F., Senécal, C., Gauthier, L., \& Fernet, C. (2003). Predicting career indecision: A selfdetermination theory perspective. Journal of Counseling Psychology, 50(2), 165-177. https://doi.org/10.1037/0022-0167.50.2.165

Hakanen, J. J., \& Schaufeli, W. B. (2012). Do burnout and work engagement predict depressive symptoms and life satisfaction? A three-wave seven-year prospective study. Journal of Affective Disorders, 141(2-3), 415-424. https://doi.org/10.1016/j.jad.2012.02.043

Hicks, D. (2005). The Four Literatures of Social Science. In H. F. Moed, W. Glanzel, \& U. Schmoch (Eds.), Handbook of Quantitative Science and Technology Research The Use of Publication and Patent Statistics in Studies of S\&T Systems edited (pp. 473-496). Retrieved from http://yunus.hacettepe.edu.tr/ tonta/courses/spring2011/bby704/Handbook of Quantitative Science and Technology Research.pdf\#page $=467$

Hirschi, A., Lee, B., Porfeli, E. J., \& Vondracek, F. W. (2013). Proactive motivation and engagement in career behaviors: Investigating direct, mediated, and moderated effects. Journal of Vocational Behavior, 83(1), 31-40. https://doi.org/10.1016/j.jvb.2013.02.003

Hoy, A. W., \& Spero, R. B. (2005). Changes in teacher efficacy during the early years of teaching: A comparison of four measures. Teaching and Teacher Education, 21(4), 343-356. https://doi.org/10.1016/j.tate.2005.01.007

Hutchins, H. M., Penney, L. M., \& Sublett, L. W. (2018). What imposters risk at work: Exploring imposter phenomenon, stress coping, and job outcomes. Human Resource Development Quarterly, 29(1), 31-48. https://doi.org/10.1002/hrdq.21304

Jones, S. G., Momin, S. R., Good, M. W., Shea, T. K., \& Patric, K. (2009). Distal upper and lower limb fractures associated with thiazolidinedione use. American Journal of Managed Care, 15(8), 491-496. https://doi.org/10.1177/0193945916659507

Judith, P., Tims, M., Akkermans, J., Khapova, S. N., Jansen, P. G. W., \& Bakker, A. B. (2016). Career competencies and job crafting: How proactive employees influence their well-being. Career Development International, 21(6), 587-602. https://doi.org/http://dx.doi.org/10.1108/MRR-09-2015-0216

Karoly, P. (1993). Mechanisms of self-regulation: A systems view. Annual Review of Psychology, 44(JANUARY 1993), 23-52. https://doi.org/10.1146/annurev.psych.44.1.23 
Kenrick, D. T., \& Dantchik, A. (1983). Interactionism, idiographics, and the social psychological invasion of personality. Journal of Personality, 51(3), 286-307. https://doi.org/10.1111/j.1467-6494.1983.tb00335.x

Khajehpour, M., Ghazvini, S. D., Memari, E., \& Rahmani, M. (2011). Social cognitive theory of gender development and differentiation. Procedia - Social and Behavioral Sciences, 15(November 1999), 1188-1198. https://doi.org/10.1016/j.sbspro.2011.03.261

Kirsch, I., Lynn, S. J., Vigorito, M., \& Miller, R. R. (2004). The Role of Cognition in Classical and Operant Conditioning. Journal of Clinical Psychology, 60(4), 369-392. https://doi.org/10.1002/jclp.10251

Kooij, D. T. A. M., van Woerkom, M., Wilkenloh, J., Dorenbosch, L., \& Denissen, J. J. A. (2017). Job crafting towards strengths and interests: The effects of a job crafting intervention on person-job fit and the role of age. Journal of Applied Psychology, 102(6), 971-981. https://doi.org/10.1037/apl0000194

Lajoie, S. P., Naismith, L., Health, M., \& Poitras, E. G. (2013). International Handbook of Metacognition and Learning Technologies. 28(March). https://doi.org/10.1007/9781-4419-5546-3

Lam, S., Kraus, F., \& Ahearne, M. (2010). The diffusion of market orientation throughout the rganization: A Social LearningTheory perspective. Journal of Marketing, 74, 9-61-79.

Lambropoulos, N. (2004). Greek Teachers' Online Community of Practice: who we are, what we do and how. The World Conference on Educational Multimedia, Hypermedia and Telecommunications, Lugano, Switzerland.

Lavoie, R. G., Ouellet, M., Hamelin, J., \& Bénard, P. (2004). Self-regulated learning, Social Cognitive Theory and agency. Educational Psychologist, 39(2), 135-145. https://doi.org/10.1207/s15326985ep3902

Lewin, K. (1936). Principles Of Topological Phychology. In McGraw-Hill. https://doi.org/10.1037/h0051703

Lewis, A., Smith, D., \& Lewis, A. (1993). Defining Higher Order Thinking. Theory Into Practice, 32(3), 131-137.

MArcuss, B., Selby, V., Niaura, R., \& Rossi, J. (1992). Self-efficacy and the stages of exercise behaviour change. Research Quarterly for Exercise and Sport, 63(5-6), 60-66.

Mathibe, I. R. (2008). Expectancy theory and its implications for employee motivation. Academic Leadership, 6(3), 1-16.

Mattarelli, E., \& Tagliaventi, M. R. (2015). How Offshore Professionals' Job Dissatisfaction Can Promote Further Offshoring: Organizational Outcomes of Job Crafting. Journal of Management Studies, 52(5), 585-620. https://doi.org/10.1111/j.14676486.2012.01088.x

McAleer, C. (1975). Life planning-An action oriented, self-directed approach.

McAuley, E. (1992). The role of efficacy cognitions in the prediction of exercise behavior in middle-aged adults. Journal of Behavioral Medicine, 15(1), 65-88. https://doi.org/10.1007/BF00848378

McCormick, M. (2001). Self-efficacy and leadership effectiveness: applying Social Cognitive Theory to leadership. Journal of Leadership Studies, 8(1), 22-33. https://doi.org/10.1177/107179190100800102

Merriam, S. B. (1995). What can you tell from an $\mathrm{N}$ of 1 ? Issues of validity and reliability in qualitative research. PAACE Journal of Lifelong Learning, Vol. 4, pp. 51-60. https://doi.org/http://dx.doi.org.esc-web.lib.cbs.dk/10.4135/9781849208970.n10 
Mullan, M., Ormcauley, W., \& Duncan. (1997). Variations in Self-Determination Across the Stages of Change for Exercise in Adults. Motivation and Emotion, 24(4), 349-362. https://doi.org/10.1023/a:1024436423492

Nabavi, R. T. (2015). Bandura's Social Learning Theory \& Social Cognitive Learning Theory Theories of Developmental Psychology Title : Bandura's Social Learning Theory \& Social Cognitive Learning Theory. (October). https://doi.org/10.1007/BF01173488

Neziroglu, F., Khemlani-Patel, S., \& Veale, D. (2008). Social learning theory and cognitive behavioral models of body dysmorphic disorder. Body Image, 5(1), 28-38. https://doi.org/10.1016/j.bodyim.2008.01.002

Hairi, N. O., Awang, A., \& Manaf, A. A. (2012). Integriti dari perspektif pengaduan awam: kajian kes di Jabatan Pengangkutan Jalan (JPJ) Malaysia. E-Bangi : Journal of Social Sciences and Humanities, 7(1), 141-155.

Parker, S., Bindl, U., \& Strauss, K. (2010). Making Things Happen: A Model of Proactive Motivation. Journal of Management, 36(4), 827-856. https://doi.org/10.1177/0149206310363732

Parker, S. K. (2013). Beyond Motivation: Job and Work Design for Development, Health, Ambidexterity, and More. Annual Review Psychology, 65, 661-691. https://doi.org/10.1146/annurev-psych-010213-115208

Parker, S. K., Wang, Y., \& Liao, J. (2019). When Is Proactivity Wise? A Review of Factors That Influence the Individual Outcomes of Proactive Behavior. Annual Review of Organizational Psychology and Organizational Behavior, 6(1), annurev-orgpsych012218-015302. https://doi.org/10.1146/annurev-orgpsych-012218-015302

Parker, S. K., \& Wang, Y. (2015). Helping people to "make things happen": A framework for proactivity at work. International Coaching Psychology Review, 10(1), 62-75.

Retrieved from http://www.researchgate.net/profile/Sharon_Parker5/publication/272821927_Help ing_people_to_'make_things_happen'_A_framework_for_proactivity_at_work/links /54f01c0f0cf25f74d723bf34.pdf

Patrick, H., Knee, C. R., Canevello, A., \& Lonsbary, C. (2007). The role of need fulfillment in relationship functioning and well-being: A self-determination theory perspective. Journal of Personality and Social Psychology, 92(3), 434-457. https://doi.org/10.1037/0022-3514.92.3.434

Peeters, M. C. W., Arts, R., \& Demerouti, E. (2016). The crossover of job crafting between coworkers and its relationship with adaptivity. European Journal of Work and Organizational Psychology, 25(6), 819-832. https://doi.org/10.1080/1359432X.2016.1160891

Peng, C. (2018). A Literature Review of Job Crafting and Its Related Researches. Journal of Human Resource and Sustainability Studies, 06(01), 1-7. https://doi.org/10.4236/jhrss.2018.61022

Petrou, P., Demerouti, E., Peeters, M. C. W., Schaufeli, W. B., \& Hetland, J. (2012). Crafting a job on a daily basis: Contextual correlates and the link to work engagement Conceptualizing Job Crafting as a Daily Behavior Job Crafting : Conceptualization and Dimensionality. Journal of Organizational Behavior, (January). https://doi.org/10.1002/job

Rastogi, M., \& Richa, C. (1999). Job crafting and work-family enrichment: the role of positive intrinsic work engagement Mansi. Personnel Review. https://doi.org/10.1108/09574090910954864 
Richman, L. S., \& Lattanner, M. R. (2014). Self-regulatory processes underlying structural stigma and health. Social Science and Medicine, 103, 94-100. https://doi.org/10.1016/j.socscimed.2013.12.029

Rido, A., Nambiar, R. M. K., \& Ibrahim, N. (2016). Teaching and classroom management strategies of Indonesian master teachers: Investigating a vocational English classroom. 3L: Language, Linguistics, Literature, 22(3), 93-109. https://doi.org/10.17576/3L-2016-2203-07

Robbins, T. (2002). The 5-choice serial reaction time task: behavioural pharmacology and functional neurochemistry Received: Psychopharmacology, 163(3), 362-380. https://doi.org/10.1007/s00213-002-1154-7

Rofcanin, Y., Berber, A., Koch, S., \& Sevinc, L. (2016). Job crafting and I-deals: a study testing the nomological network of proactive behaviors. International Journal of Human Resource Management, 27(22), 2695-2726. https://doi.org/10.1080/09585192.2015.1091370

Roseman, I. J. (2013). Appraisal in the Emotion System: Coherence in Strategies for Coping. Emotion Review, 5(2), 141-149. https://doi.org/10.1177/1754073912469591

Rosenstock, I. M., Strecher, V. J., \& Becker, M. H. (1998). Social Learning Theory and the Health Belief Model. Health Education Quarterly, 15(2), 175-183. https://doi.org/10.1177/109019818801500203

Rosenthal, T., \& Zimmerman, B. (1978). Social Learning and Cognition. Academic Press.

Rotter, J. B. (1971). Generalized expectancies for interpersonal trust. American Psychologist, 26(5), 443-452. https://doi.org/10.2466/pr0.1976.39.2.649

Schaufeli, W. B., Bakker, A. B., \& Salanova, M. (2006). The Measurement of Short Questionnaire: A Cross-National Study. Educational and Psychological Measurement, 66(4), 701-716. https://doi.org/10.1177/0013164405282471

Schunk, D. (1991). Self-efficacy and academic motivation. Educational Psychologist, 26(9), 207-231.

Seigfried-Spellar, K. C., \& Rogers, M. K. (2010). Low neuroticism and high hedonistic traits for female internet child pornography consumers. Cyberpsychology, Behavior, and Social Networking, 13(6), 629-635. https://doi.org/10.1089/cyber.2009.0212

Shin, Y., \& Kim, M.-J. (2014). Antecedents and Mediating Mechanisms of Proactive Behavior: Application of the Theory of Planned Behavior. Asia Pacific Journal of Management. https://doi.org/10.1007/s10490-014-9393-9

Skinner, B. F. (2014). Verbal Behavior. https://doi.org/10.1037/11256-000

Slemp, G. R., Kern, M. L., \& Vella-Brodrick, D. A. (2015). Workplace Well-Being: The Role of Job Crafting and Autonomy Support. Psychology of Well-Being, 5(1), 7. https://doi.org/10.1186/s13612-015-0034-y

Staddon, J. E. (1984). Social learning theory and the dynamics of interaction. Psychological Review, 91(4), 502-507. https://doi.org/10.1037/0033-295X.91.4.502

Strauss, K., Griffin, M. A., \& Parker, S. K. (2012). Future Work Selves : How Salient Hoped-For Identities Motivate Proactive Career Behaviors. 97(3), 580-598. https://doi.org/10.1037/a0026423

Strauss, K., \& Parker, S. K. (2014). Effective and Sustained Proactivity in the Workplace: A Self-Determination Theory Perspective. The Oxford Handbook of Work Engagement, Motivation, and Self-Determination Theory, 50.

Strauss, K., \& Parker, S. K. (2018). Intervening to Enhance Proactivity in Organizations: Improving the Present or Changing the Future. Journal of Management, 44(3), 1250- 
1278. https://doi.org/10.1177/0149206315602531

Swearer, S. M., Wang, C., Berry, B., \& Myers, Z. R. (2014). Reducing bullying: application of Social Cognitive Theory. Theory into Practice, 53(4), 271-277. https://doi.org/10.1080/00405841.2014.947221

Thang, S. M., Mahmud, N., \& Abd Razak, N. (2012). The use of wireless technology in UKM: Challenges faced and its impact on English language learning. 3L: Language, Linguistics, Literature, 18(1), 129-143.

Thompson, J. A. (2005). Proactive personality and job performance: a social capital perspective. The Journal of Applied Psychology, 90(5), 1011-1017. https://doi.org/10.1037/0021-9010.90.5.1011

Thun, S., \& Bakker, A. B. (2018). Empowering leadership and job crafting: The role of employee optimism. Stress and Health, 34(4), 573-581. https://doi.org/10.1002/smi.2818

Tims, M., Bakker, A. B., \& Derks, D. (2012). Development and validation of the job crafting scale. Journal of Vocational Behavior, 80(1), 173-186. https://doi.org/10.1016/j.jvb.2011.05.009

Tu, C. H. (2000). On-line learning migration: From social learning theory to social presence theory in a CMC environment. Journal of Network and Computer Applications, 23(1), 27-37. https://doi.org/10.1006/jnca.1999.0099

Van den Broeck, A., Schreurs, B., De Witte, H., Vansteenkiste, M., Germeys, F., \& Schaufeli, W. (2011). Understanding Workaholics' Motivations: A Self-Determination Perspective. Applied Psychology, 60(4), 600-621. https://doi.org/10.1111/j.14640597.2011.00449.x

Van der Rijt, J., Van den Bossche, P., Van de Wiel, M. W. J., Segers, M. S. R., \& Gijselaers, W. H. (2012). The role of individual and organizational characteristics in feedback seeking behaviour in the initial career stage. Human Resource Development International, 15(3), 283-301. https://doi.org/10.1080/13678868.2012.689216

Victor J. S., DeVellis, B. M., Becker, M. H., \& Rosenstock, I. M. (1986). The Role of SelfEfficacy in Achieving Health Behavior Change. Health Education Quarterly, 13(1), 7391. Retrieved from http://ci.nii.ac.jp/naid/40020981469/

Vohs, K. D., \& Baumeister, R. F. (2011). Handbook of self-regulation: Research, theory, and applications. New York: Guilford Press.

Wang, W. T., \& Hou, Y. P. (2015). Motivations of employees' knowledge sharing behaviors: A self-determination perspective. Information and Organization, 25(1), 1-26. https://doi.org/10.1016/j.infoandorg.2014.11.001

Ward, V., West, R., Smith, S., McDermott, S., Keen, J., Pawson, R., \& House, A. (2014). The role of informal networks in creating knowledge among health-care managers: a prospective case study. Health Services and Delivery Research, 2(12), 1-132. https://doi.org/10.3310/hsdr02120

Williams, H. M., Parker, S. K., \& Turner, N. (2010). Proactively performing teams: The role of work design, transformational leadership, and team composition. Journal of Occupational and Organizational Psychology, 83(2), 301-324. https://doi.org/10.1348/096317910X502494

Williams, S., Gray, L., \& Broembsen, M. H. V. (1972). Proactivity and Reinforcement: The Contigency of Social Behaviour. Small Group Behaviour, 7(3), 317-330.

Wilson, P. M., Mack, D. E., \& Grattan, K. P. (2008). Understanding motivation for exercise: A self-determination theory perspective. Canadian Psychology/Psychologie 
Canadienne, 49(3), 250-256. https://doi.org/10.1037/a0012762

Wolpe, J., \& Plaud, J. J. (1997). Pavlov's contributions to behavior therapy. The obvious and not so obvious. The American Psychologist, 52(9), 966-972. https://doi.org/10.1037/0003-066X.52.9.966

Wood, R., \& Bandura, A. (1989). Social Cognitive Theory of organizational management. Academy of Management Review, 14(3), 361-384. https://doi.org/10.5465/AMR.1989.4279067

Wu, C.-H., Parker, S. K., \& Bindl, U. K. (2013). Who is Proactive and Why? Unpacking Individual Differences in Employee Proactivity. In Advances in Positive Organizational Psychology (Vol. 1). https://doi.org/10.1108/S2046410X(2013)0000001014

Yi, M. Y., \& Hwang, Y. (2003). Predicting the use of web-based information systems: Selfefficacy, enjoyment, learning goal orientation, and the technology acceptance model. International Journal of Human Computer Studies, 59(4), 431-449. https://doi.org/10.1016/S1071-5819(03)00114-9

Zakaria, E., Aun, N. S., \& Hamat, W. (2018). Hubungan antara Stigma terhadap Anak Yatim AIDS, Tekanan Persekitaran dan Pengurusan Penjagaan Kanak-kanak HIV/AIDS di Institusi Perlindungan Kanak- kanak: Satu Kajian Awal. Jurnal Psikologi Malaysia, 32(4), 1-17.

Zhang, F., \& Parker, S. K. (2018). Reorienting job crafting research: A hierarchical structure of job crafting concepts and integrative review. Journal of Organizational Behavior, (September), 1-21. https://doi.org/10.1002/job.2332

Zhao, L., Lu, Y., Wang, B., \& Huang, W. (2011). What makes them happy and curious online? An empirical study on high school students' Internet use from a self-determination theory perspective. Computers and Education, 56(2), 346-356. https://doi.org/10.1016/j.compedu.2010.08.006

Zimmerman, B. (2014). Self-efficacy in changing societies (A. Bandura, Ed.). https://doi.org/10.1017/CBO9780511527692.009

Zimmerman, B. J., Bandura, A., \& Martinez-Pons, M. (1992). Self-motivation for academic attainment: the role of self-efficacy beliefs and personal goal setting. American Educational Research Journal, 29(3), 663-676. https://doi.org/10.3102/00028312029003663

Zimmerman, B. J. (2000). Self-Efficacy: An Essential Motive to Learn. Contemporary Educational Psychology, 25(1), 82-91. https://doi.org/10.1006/ceps.1999.1016 